\title{
Seasons for Music and Major Rituals
}

The musical seasons, especially for the shaken bamboos ensemble angklung and the keromong are related to the agricultural seasons and the connected social events. The agricultural yearly cycle starts with clearing the fields and is followed by planting rice around September-November, offering harvested products to the rulers (séba) in the period April-June, and it ends with circumcisions and weddings around June-August. Section 4.1 will discuss the agricultural calendar and the connected music and dance activities. The Baduy calendar is based on both solar and lunar calendars. Each year the spiritual leaders may make adjustments to the calendar, so that it better fits the solar year. That makes the exact Baduy date and month sometimes difficult to predict (see further Appendix 2).

This chapter will also describe a few rituals that I attended, focussing on the music and dance that were used. For researchers it is not easy to obtain permission for attending rituals: one needs to be trusted by the Baduy, and this usually only takes place after several visits to Kanékés, as was also explained in Chapter 3. This chapter will focus on the music and dance during circumcision rituals and the connected keromong music and pantun storytelling. A description of the ritual in which the rice goddess Nyi Pohaci Sang $(\mathrm{h}) \mathrm{i}(\mathrm{y})$ ang Asri was married off to the Earth was presented in Van Zanten (1995). Here I will only summarize that important rice ritual with angklung music and dance and also describe a few other rituals that I was not able to attend.

Not all Baduy music and dance is used in rituals. Moreover, the angklung and keromong ensembles that are used in rituals, are also frequently played for entertainment outside a ritual. Those occasions may be seen as a kind of rehearsal in which the players improve their playing skills and learn new songs. Especially during these occasions the musical skills are passed on to younger generations of boys and men. Instruments for one's own and some neighbours' entertainment, like the flutes, the Jew's harp and the zither and violin, may be played almost every day and are not restricted by a season. Those instruments can always be played except for the two or three fasting days in each of the three kawalu months.

\subsection{Agricultural Calendar and Musical Seasons}

Baduy are in the first place farmers and rice grown on dry fields (huma) is an essential part of their living and religion. Currently irrigated rice fields (sawah) 
are strictly forbidden in Kanékés. This also holds for the fields near the hamlets of Cicakal Girang in Kanékés, where Muslim people live, as we have already mentioned in Section 2.3. The Baduy leaders only tolerate that there are sawah in this Muslim enclave in Kanékés, that is, the sawah are only allowed to people who are not part of the Baduy community.

Baduy keep their own rice sometimes for many years in the storage barn (leuit) and they are not allowed to sell this rice. However, if the harvest was poor, they are allowed to buy rice on the markets outside Kanékés. The Baduy year is regulated by agricultural activities, from clearing the fields to harvesting the rice. The time for planting rice is determined by the spiritual leaders and it is a complicated issue: the Baduy calendar is a solar calendar (that is, following the seasons of the solar year) but also based on 12 lunar months of 29 or 30 days. That means that adjustments have to be made to fit the shorter lunar year of 12 months (about 355 days) to the solar year of $365^{1 / 4}$ days. These adjustments by the puun and their closest assistants seem to be made by extending the duration of the month Hapit Kayu (see further Appendix 2).

The séba ceremony marks the end of the old and the beginning of the new agricultural season. During the séba Baduy men travel to the 'rulers of the north' and offer them some of their products as a sign of appreciation for their protection of the Baduy community; see Section 2.4 above. The séba should start in Kanékés at the beginning of the Baduy month Kapat/Sapar on one of the odd dates 1, 3, 5 or 7. From Tables 31 and 32 in Appendix 2 it follows that since the beginning of the 1970s the Baduy agricultural year started between the beginning of April and the beginning of June. For simplicity reasons we could assume that 'on average' the Baduy agricultural year starts on 1 May ('on average' the same as 1 Kapat/Sapar) with a margin of one month earlier or later.

Garna (1988: 338) mentions that the séba in fact already starts at the end of the third fasting month (kawalu tutug) with offerings of small puppets made of rice flour vermicelli (laksa) to the spirits (guriang) in the forbidden forest (leuweung larangan) in the Inner Baduy area. These spirits are in fact ancestors who look after and protect Kanékés village. They are the 'spiritual rulers' (penguasa gaib), who get the offerings before the worldly rules of the north.

In Table 5 I have listed the Baduy calendar, together with the Western calendar, the agricultural activities and the major social activities with performing arts that play a role on the level of the whole Baduy community (angklung) and that mainly affect the hamlet level (pantun, keromong). Pantun and most other music on the hamlet level may be played during the whole season, although it is not allowed during some days of the fasting (kawalu) months around February-April. Apart from marriages and circumcisions, the initiation of a newly formed hamlet (nukuh lembur) is also a ritual which mainly affects 
the hamlet level and pantun is used for that ritual. Pantun recitation is also used for curing the rice from diseases, ascertain a successful hunt, curing human beings from illnesses and for purification rituals, needed when one of the Baduy rules of living has been breached.

The major rituals concerning Baduy individuals are birth, circumcision, marriage and death. Circumcision and marriage are very much considered communal affairs that involve performing arts and take place in a special season, as indicated in Table 5 below. Birth and death require rituals that are more oriented towards the individual and her/his family and do not involve any music or dance, as far as I know. I only heard that at funerals women may show their respect for the deceased by individually pounding rice, not in a group as in gendék (A2013: 22).

If the music is played outside Kanékés the musical seasons are less strictly observed during the last decades. For instance, there are many examples of a Baduy angklung group playing outside Kanékés and outside the season. It was said that on the 2 oth July 2016 the Kaduketug angklung group would have played in Cibolégér, just outside Kanékés, to receive Indonesia's president. This date fell outside the angklung season - and the president did not come (Van Zanten 2017: 96).

In 1995 I wrote that the gamelan (keromong) and angklung seasons exclude each other:

The gamelan can be played only between the end of the harvest ceremonies, marked by the presentation of agricultural products to the rulers (séba) around the first of June, and the beginning of the rice-planting season, around the first of September. Angklung and gamelan are not allowed to be played in the same season; this is forbidden (buyut). The angklung season starts when the gamelan season ends.

VAN ZANTEN 1995: $5^{28}$

This statement has to be adjusted on the basis of my later fieldwork: the keromong may also be played in the Baduy month Hapit Kayu for weddings and circumcisions of girls, just before the three kawalu fasting months start around January-February (Sapin and Arwan, A2013: 21).

During the marriage of jaro Daénah's son Pulung in the beginning of January 2014 the keromong was played. Hence from the information I gathered the present keromong season is longer than it was in the 1970s and before and it overlaps the angklung (and pantun) season.

It would be better to say that these two types of music belong to different worlds: ritual angklung music for the goddess of rice (Déwi Asri/Déwi Sri/ 


\begin{tabular}{|c|c|c|c|c|}
\hline $\begin{array}{l}\text { Month } \\
\#\end{array}$ & $\begin{array}{l}\text { Baduy } \\
\text { name }\end{array}$ & $\begin{array}{l}\text { Approximate } \\
\text { Western } \\
\text { month } \\
\text { ('average') }\end{array}$ & $\begin{array}{l}\text { Agricultural } \\
\text { activities (Geise } \\
\text { 1952: 32-65; } \\
\text { Danasasmita } \\
\text { and Djatisunda } \\
\text { 1986: 40-49; Garna } \\
\text { 1987: 90; Garna } \\
\text { 1988: } 84 \text {; Iskandar } \\
\text { 1992: } 65^{-67} \text { ) }\end{array}$ & $\begin{array}{l}\text { Major social activities and } \\
\text { accompanying music and } \\
\text { dance }\end{array}$ \\
\hline 1 & $\begin{array}{l}\text { Kapat/ } \\
\text { Sapar }\end{array}$ & May & $\begin{array}{l}\text { Clearing (ngarawas) } \\
\text { the huma sérang field } \\
\text { in Inner Baduy area }\end{array}$ & $\begin{array}{l}\text { Séba delegation leaves } \\
\text { Kanékés for gifts to the } \\
\text { authorities in Rangkasbitung } \\
\text { and Sérang on } 1,3,5 \text { or } 7 \\
\text { Sapar }\end{array}$ \\
\hline 2 & Kalima & June & $\begin{array}{l}\text { Cutting trees and } \\
\text { bushes (nyacar) on } \\
\text { the huma sérang }\end{array}$ & $\begin{array}{l}\text { Circumcisions, and } \\
\text { marriages: pantun and } \\
\text { keromong (gamelan); } \\
\text { initiation of new hamlets } \\
\text { (nukuh lembur): pantun }\end{array}$ \\
\hline 3 & Kanem & July & $\begin{array}{l}\text { Drying the grass, cut } \\
\text { branches and shrubs } \\
\text { to be burned (nukuh- } \\
\text { ganggan) on huma } \\
\text { sérang }\end{array}$ & $\begin{array}{l}\text { Circumcisions, and } \\
\text { marriages: pantun and } \\
\text { keromong; initiation of } \\
\text { new hamlets (nukuh } \\
\text { lembur): pantun }\end{array}$ \\
\hline 4 & Kapitu & August & $\begin{array}{l}\text { Burning of wood } \\
\text { (ngaduruk) and start } \\
\text { of ritual sowing of } \\
\text { rice on huma sérang } \\
\text { in Inner Baduy area } \\
\text { (ngaseuk-muuhan) }\end{array}$ & $\begin{array}{l}\text { Angklung season begins with } \\
\text { 'engagement' of rice goddess } \\
\text { to the earth: ngarérémokeun } \\
\text { ritual before the planting of } \\
\text { rice (ngaseuk-muuhan) in } \\
\text { the Inner Baduy area. The } \\
\text { Outer Baduy keromong is } \\
\text { hardly played until about } \\
\text { January }\end{array}$ \\
\hline 5 & Kadalapan & September & $\begin{array}{l}\text { Start sowing of rice } \\
\text { on the fields of the } \\
\text { three puun (ngaseuk) }\end{array}$ & $\begin{array}{l}\text { Angklung played for } \\
\text { entertainment in Outer } \\
\text { Baduy area }\end{array}$ \\
\hline
\end{tabular}




\begin{tabular}{|c|c|c|c|c|}
\hline $\begin{array}{l}\text { Month } \\
\#\end{array}$ & $\begin{array}{l}\text { Baduy } \\
\text { name }\end{array}$ & $\begin{array}{l}\text { Approximate } \\
\text { Western } \\
\text { month } \\
\text { ('average') }\end{array}$ & $\begin{array}{l}\text { Agricultural } \\
\text { activities (Geise } \\
\text { 1952: 32-65; } \\
\text { Danasasmita } \\
\text { and Djatisunda } \\
\text { 1986: 40-49; Garna } \\
\text { 1987: 90; Garna } \\
\text { 1988: 84; Iskandar } \\
\text { 1992: } 65-67 \text { ) }\end{array}$ & $\begin{array}{l}\text { Major social activities and } \\
\text { accompanying music and } \\
\text { dance }\end{array}$ \\
\hline 6 & Kasalapan & October & $\begin{array}{l}\text { Start sowing of } \\
\text { rice on the fields of } \\
\text { commoners in Inner } \\
\text { Baduy area (ngaseuk) }\end{array}$ & $\begin{array}{l}\text { Angklung played for } \\
\text { entertainment in Outer } \\
\text { Baduy area }\end{array}$ \\
\hline 7 & Kasapuluh & November & $\begin{array}{l}\text { Ritual sowing of } \\
\text { rice on Outer Baduy } \\
\text { common field } \\
\text { (huma tuladan) and } \\
\text { weeding (ngoréd) on } \\
\text { Inner Baduy fields }\end{array}$ & $\begin{array}{l}\text { Angklung used for } \\
\text { ngarérémokeun ritual in } \\
\text { Outer Baduy area and played } \\
\text { for entertainment in Outer } \\
\text { Baduy area }\end{array}$ \\
\hline 8 & $\begin{array}{l}\text { Hapit } \\
\text { Lemah }\end{array}$ & December & $\begin{array}{l}\text { Weeding (ngirab } \\
\text { sawan) and giving } \\
\text { medicine to the rice } \\
\text { (ngubaran) }\end{array}$ & $\begin{array}{l}\text { Angklung and pantun used } \\
\text { as medicine for curing the } \\
\text { rice }\end{array}$ \\
\hline 9 & $\begin{array}{l}\text { Hapit } \\
\text { Kayu }\end{array}$ & January & $\begin{array}{l}\text { Waiting for the rice } \\
\text { to grow (menunggu } \\
\text { ladang) }\end{array}$ & $\begin{array}{l}\text { Angklung and pantun used } \\
\text { as medicine for curing the } \\
\text { rice; keromong played at } \\
\text { weddings }\end{array}$ \\
\hline 10 & Kasa & February & $\begin{array}{l}\text { Kawalu mitembey; } \\
\text { start harvesting the } \\
\text { rice from the huma } \\
\text { sérang in Inner } \\
\text { Baduy area }\end{array}$ & $\begin{array}{l}\text { First month of fasting; no } \\
\text { angklung or keromong, but } \\
\text { individual instruments } \\
\text { (flutes, Jew's harp, zither, } \\
\text { etc.) may be played, except } \\
\text { for the fasting day ( } 17 \text { Kasa) }\end{array}$ \\
\hline 11 & Karo & March & $\begin{array}{l}\text { Kawalu tengah. } \\
\text { Harvesting and } \\
\text { hunting }\end{array}$ & $\begin{array}{l}\text { Second month of fasting; } \\
\text { individual instruments may } \\
\text { be played, except for the } \\
\text { fasting day (18 Karo) }\end{array}$ \\
\hline
\end{tabular}




\begin{tabular}{|c|c|c|c|c|}
\hline $\begin{array}{l}\text { Month } \\
\#\end{array}$ & $\begin{array}{l}\text { Baduy } \\
\text { name }\end{array}$ & $\begin{array}{l}\text { Approximate } \\
\text { Western } \\
\text { month } \\
\text { ('average') }\end{array}$ & $\begin{array}{l}\text { Agricultural } \\
\text { activities (Geise } \\
\text { 1952: 32-65; } \\
\text { Danasasmita } \\
\text { and Djatisunda } \\
\text { 1986: 40-49; Garna } \\
\text { 1987: 90; Garna } \\
\text { 1988: } 84 ; \text { Iskandar } \\
\text { 1992: } 65-67 \text { ) }\end{array}$ & $\begin{array}{l}\text { Major social activities and } \\
\text { accompanying music and } \\
\text { dance }\end{array}$ \\
\hline 12 & Katiga & April & $\begin{array}{l}\text { Kawalu tutug. } \\
\text { Harvesting and } \\
\text { hunting. }\end{array}$ & $\begin{array}{l}\text { Last month of fasting. } \\
\text { Cleaning the holy sites } \\
\text { near Cikeusik and Cibéo, } \\
\text { ngalaksa festivities with } \\
\text { preparations for séba; } \\
\text { individual instruments may } \\
\text { be played, except for the } \\
\text { fasting days (17-19 Katiga) }\end{array}$ \\
\hline
\end{tabular}

Nyi Pohaci) and other deities in the upper world and keromong and nonritual angklung music for human beings in the middle world. ${ }^{1}$ Therefore the sounds of ritual angklung and keromong music should be kept apart. When on 23 October 1992 I attended the ceremonial planting of rice with angklung music on the Outer Baduy field (huma tuladan) near Cicakal Hilir (nowadays called Cicakal Muara) from a distance, as described in Van Zanten (1995: 532-535), our party heard a boy hitting one of the gongs in a

1 In the Baduy belief system there are three worlds that a human being passes from the time before birth until after death. Those three worlds are each ruled by a 'mother', Ambu (Garna 1988: 238-243; Permana 2001: 66-68). The upper world (buana nyungcung or buana luhur) is where the gods (batara) and spirits live, including the highest god Batara Tunggal, the rice goddess Nyi Pohaci Sangiang Asri (Déwi Sri) and the godly mother Sunan Ambu. Before human beings are born, their spirits also are in this upper world. The middle world (buana (panca) tengah) is where the human beings (manusa) live. The underworld (buana rarang/larang) is where the dead stay for seven days, before their spirits go back to the upper world and are united with the gods. See further, for instance, Garna (1987: 88-89) and Ekadjati (1995: 72-74). 
keromong set. Immediately one of the elder people said that this was forbidden (pamali), as it was now time for the ritual planting of rice (ngaseuk or ngaseuk-muuhan). He also said that the time for keromong sound was during the months 5 (Kalima) to 7 (Kapitu), which is roughly between June and August (A1992-1: 66).

On 1 July 2016 the jaro pamaréntah Saijah also remarked that 'angklung and keromong should not sound together' (A2016-1: 1-2). There is music for the gods, and specifically the rice goddess Nyi Pohaci Sangiang Asri and her children, and music for human beings during the feasts, like weddings (nikahan, kawinan) and circumcisions (sunatan for boys, peupeuran for girls). Angklung is the major music for the gods, especially played when the goddess of rice is engaged and married to the earth at the beginning of the planting season (Section 4.2). Keromong and pantun are both used during the human weddings and circumcisions (Section 4.3). With the Outer Baduy angklung music is also used for entertainment and dancing of men and the texts are then mainly about love (see texts in Appendix 4).

\subsection{Angklung Music for the Engagement Ritual of the Goddess of Rice}

This section is based on Van Zanten (1995: 532-537) and with some additional information. In the Outer Baduy region the angklung is played in combination with singing and dancing by men. There are two different social settings in which angklung music is used: a setting in which it is used for entertainment and a ritual setting. When the angklung is used for entertainment, the male players sing sisindiran (poems in which an allusion is given, mainly by sound association) while they are playing. A soloist will sing the main text, and a chorus of players answers. This type of angklung music for entertainment is also played during the rice ritual described in this section, and the music will mainly be discussed in Section 5.2 below. The present Section 4.2 will concentrate on the ritual context of the angklung.

The angklung is closely associated with the rice rituals. It is always played during the ceremony held in the night before the ceremonial planting of rice (ngaseuk). This ritual takes place several times: first on various fields of the Inner Baduy (starting with the huma sérang, then on the fields of the puun, and at last on the fields of the commoners), and then on a special field of the Outer Baduy (huma tuladan): see Figure 32 and further Judistira Garna (1988: 321) for the complicated schedule. This ceremony is to 'wake' the goddess of rice, Nyi Pohaci Sanghyang Asri, and to announce her marriage to the earth 
(ngarérémokeun) the following morning (Geise 1952: $36-37)^{2}$ A few weeks after the planting of the rice, the earth 'gets medicine', to protect it from diseases, and the angklung is played again.

I was given permission to record the 'engagement' ceremony on audio tape in Kadujangkung during the night of 22-23 October 1992. The ceremony took place near the house of Asrab, then the secular village head. As there would also be Inner Baduy present at this ritual, I was only allowed to record from inside a house, so that those present would not see me and the recording apparatus. The recording was made from behind a plaited bamboo wall. Through two holes of $8 \times 8 \mathrm{~cm}$ in the wall, I could see what was going on outside. The angklung players and dancers passed within a metre of this wall, and the greatest distance between them and the wall was about 8 metres. As plaited bamboo is thin, most of the recordings are of good quality. Unfortunately, during the solo singing of the ceremonial text around midnight, the singers were seated on a mat on the ground and singing away from my microphones. Hence, this text is poorly recorded and difficult to understand.

The evening started around 19.00 hours, and went on until about 4.30 the following morning. Just before 19.0o, the nine different angklung instruments of Kadujangkung had been placed with the top parts together, in a roof-like shape: $\Lambda$. The two drums and some burning incense had been put under this 'roof'. Then they picked up the instruments and the playing started: eight men and boys played the angklung idiophones (the two idiophones producing the highest tones are always played by one person), and two men played the two drums (bedug and talinting). Some of the adult men had a ceremonial white sash with coloured patterns at the ends (sabuk adu mancung; see Figure 19 and photographs in Bakels 1991: 42 and Hasman and Reiss 2012: 69) around their waist. As usual, a few men sang while playing the angklung. The players walked around in a circle, of which about a quarter was open, most of the time in a counter-clockwise direction and around 21:0o hours in a clockwise direction (A1992-1: 6o). The Baduy angklung is therefore also called angklung aleutan, the angklung [played in a] 'row'. During the evening, ang klung groups from other hamlets (Cikadu, Karahkal, and Cisaban) arrived and joined in. Sometimes there were dancers among the group of players. Elsewhere I have remarked that the tunings of the different angklung sets did not match very well, but that the festive, exciting (ramé) atmosphere apparently was considered more important than

2 Garna (1988: 322) points out that in this Baduy ceremony the earth becomes the husband of the rice goddess, but that in the Nusantara traditions the earth usually falls in the female category. See also Geise (1952: 34-40). 
the musical shortcomings (Van Zanten 1997: 47-48; see also end of Section 4.5 below).

Van Hoëvell (1845: 429) already mentioned that the Baduy have angklung and he reports that 'they are not allowed [to play] the instruments when standing; they should be played when sitting. This contradicts the present situation, and Van Hoëvell's remark may have been valid for some special situations only: Ayah Sardi from Kompol told me that at the end of the ceremonial planting of rice on the special field (huma tuladan for Outer Baduy and huma sérang for Inner Baduy) the angklung players had to sit when playing, whereas in the other parts of this ritual they perform while walking around in a circle (A2014-1: 14,).

Around 23.45 hours a basket of rice was carried from the house of the village head and put on a mat in the open space. The leader of one of the groups of angklung players (jaro angklung) from the other hamlets said a formula (jampé), and incense was burnt, while other people were talking. Thereafter one angklung group started playing the song Maréngo ${ }^{3}$ while circling around the mat in a clockwise direction. This lasted for one hour. There was no dancing now. The dancers were sitting on the mat in the middle with the musicians who were not playing. This was the part of the ceremony in which the goddess of rice, Nyi Pohaci Sanghyang Asri, is engaged to the earth Partiwi. The text of the engagement song was sung alternately by the two leaders of the visiting angklung groups from Cikadu and Cisaban. Now and then players were replaced by others. When they were not playing, they would sit on the mat, or at the side, outside the circle of players, and join in with the chorus. Most of the men smoked occasionally, even while they were playing.

About $0.5^{\circ}$ hours the music stopped after a last section which was played very fast (ngagubrugkeun), and the players stood still. One of the leaders took off his ceremonial sash (sabuk), and put it on the basket of rice. Then the village head carried the basket back inside his house. A few minutes later the angklung players started again. They walked around the circle again in counterclockwise direction, and sang sisindiran, as they had done during the first part of the evening. The music and dancing went on like this until about 4.00 in the morning. Gradually most spectators had gone and were apparently sleeping somewhere, because it became quieter outside. The angklung players had stopped walking around in a circle.

3 Judistira Garna (1988: 324, 341) also gives the name Pangrérémo, which means 'engagement/ marriage song.' 
Then, around 4.00, they started playing quite differently, and without singing. It gave me the impression that they were learning tunes from each other. Later, it was explained by the village head Asrab that, indeed, most of the players did not know these last melodies very well. However, they belong to the ceremony, because they are tunes to entertain the 'children of the rice goddess, Déwi Asri'. There are three parts (melodies?): Ceuceurikan (crying), Ngupahan (comforting), Seuseurian (laughing). ${ }^{4}$ After this 'lullaby' the music stopped at about 4.30. I heard some dirty phrases being sung, but gradually it became quiet.

At 6.00 the angklung group from Cikadu started playing again. Women and men collected baskets full of rice at the house of the village head. In a long procession, about one hundred women and men followed the angklung music to the field where the rice would be planted. Some men and women carried the rice baskets on their heads, and others carried food to be eaten after the planting. ${ }^{5}$ The angklung played the farewell piece Pileuleuyan. Men and women were in ceremonial dress. Men (except the four Inner Baduy men) were wearing a black shirt without collar over a white shirt without collar, black short trousers, a black and blue head cloth of printed batik, and some of them used the ceremonial sash. Most of the women were wearing a locally woven blue and red cloth, or a black and blue cloth of printed batik, a white shirt, a ceremonial sash over their shoulder (suat samata), and a big hat of plaited bamboo (see Figure 19, Figure 7 right-top, and photographs in Bakels (1991: 38, 41-43)).

After an hour's walk, and after crossing the Ciujung River via the hanging bamboo bridge of Gajeboh, the procession reached the hamlet Cicakal Hilir (in 2016 called Cicakal Muara). Here, all the Baduy people crossed the river by wading through it, to reach the sacred field of the Outer Baduy (huma tuladan: literally, exemplary field), where the rice would be planted. ${ }^{6}$ The few nonBaduy Sundanese people, including the very popular administrator of Désa Kanékés, Ukang Sukarna, and myself, could not follow the procession across the river. The Inner Baduy, who had attended the previous night's ceremony and were also to attend this planting ceremony (ngaseuk), had said 'it was

4 See also Section 1.2 in which I mentioned that the sound of the calintuh pipes and the kolécér propeller, both blown by the wind, are also considered to be music for the children of the rice goddess, Déwi Asri.

5 According to Judistira Garna (1988: 325), in this procession they also take toys (cocooan) for Nyi Asri with them, in the form of seeds (piceun, kemiri), shells, and a sponge.

6 The rice harvested from this field is mainly used for the kawalu and ngalaksa harvest ceremonies (Judistira Garna 1988: 192). 


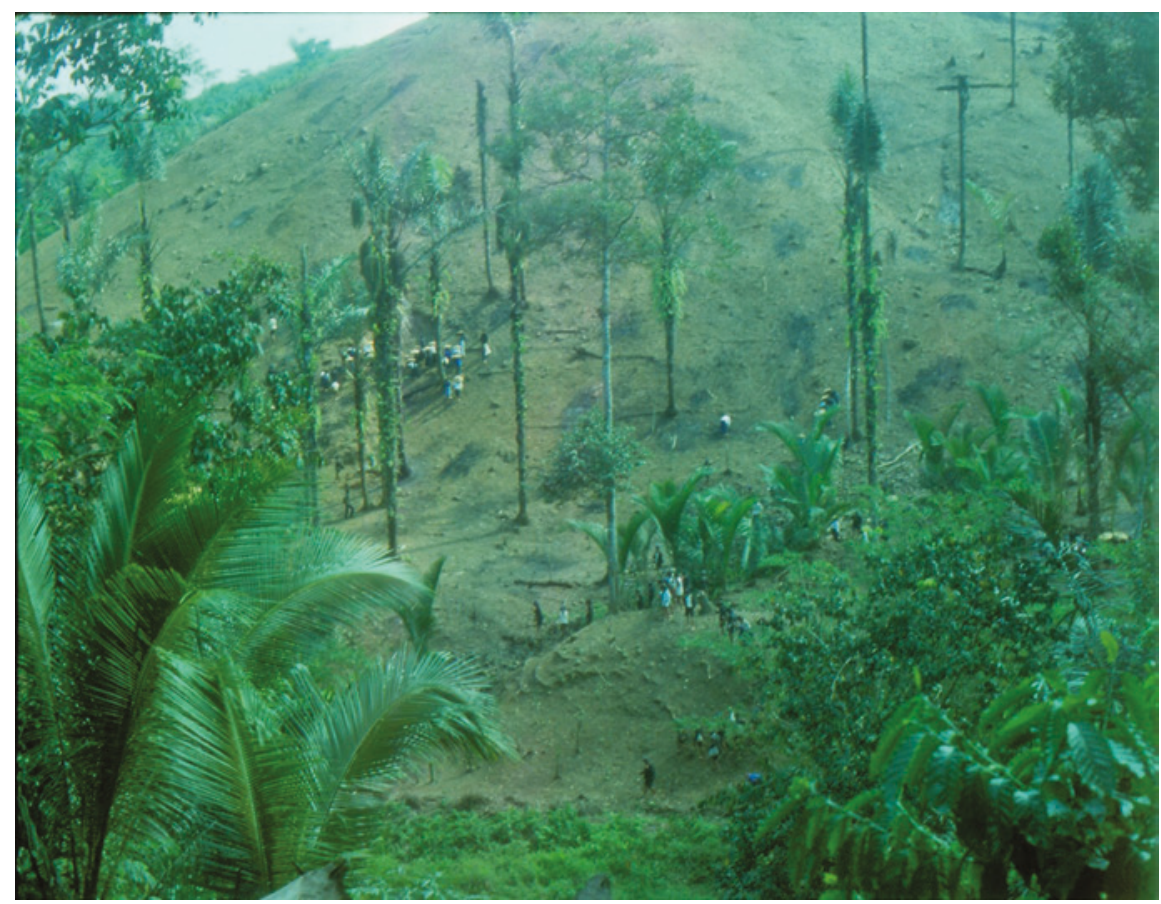

FIGURE 32 The huma tuladan field near Cicakal Hilir, morning of 23 October 1992. The procession had just reached the field and the rice would be planted there between about 8.45 and 9.45

not necessary' for us to be present at this ceremony. Slowly many more Baduy women and men arrived, until there were about 250 people assembled on the sacred field, which lies on a steep slope. The four Inner Baduy and some Outer Baduy walked over the field, as if they were inspecting it, or said prayers in all directions. I estimated the size of this field to be 1 to 1.5 ha.

The angklung played again from 7.30 to 8.45 . The 18 -some players and two dancers walked in a clockwise direction around the pungpuhunan, a sacred place covering about a square metre in the middle of the field, marked with some young sugar-palm leaves. It was here that the offerings were placed, and here where the ceremonial planting began. Prayers were said by a spiritual leader; he put rice seeds into a few holes, made with a planting stick (for a description see Geise 1952: 38-9; Judistira Garna 1988: 325). Then the angklung was put aside in the shade, and the 250 men and women started to plant rice on the whole field. They worked together in two groups. In each group the men walked with a planting stick (aseuk, tugal; Garna 1988: 198) and made holes (ngaseuk) about $20-30 \mathrm{~cm}$ apart. The women followed with the rice, putting 
five or seven seeds in each hole (muuhan). The holes were not covered over. About an hour later they were finished, and the angklung played again for about half an hour. They started eating at a large open hut (saung) which had been constructed on the field. Around 11.15 the angklung played again for a short time, and people went home.

I was told afterwards that during the ceremonial part of the evening (around midnight) the only singing done was an hour's singing of the song Maréngo. However, musically speaking, there was a definite change in the chorus part, after about half an hour's singing. The music transcription of this second part of the song Maréngo is presented in Appendix 4 of Van Zanten 1995. It was repeated for about half an hour in the transcribed way. As the recording of the soloist is very poor, I have not attempted to transcribe his text. Instead, I presented the text from Geise (1952: 37-8, 190-1) underneath my music transcription:

Pohaci Sanghiang Asri

Ku kami rék ditetepkeun

Ku kami diraramékeun

Ku kami dirérémokeun

Dina malem Ahad

Di bumi Paratiwi

Buana pancatengah

Ulah gédér, ulah reuwas

Mangka tetep, mangka

langgeng

Mangka hurip kajayana

$\mathrm{Nu}$ kosong pangeusiankeun

Nu celong

pangmeunuhankeun.
Pohaci Sanghiang Asri,

Who will be put by us at a permanent place

Who is greeted by us with festivities

Who is married off by us

On the night before Sunday

On the earth [called] Paratiwi

The central world.

Do not be afraid, do not be scared

May it be permanent, may it be forever

May her power live

The empty ones [ears], please fill them,

The lean ones, please make them full.

About one minute of this recorded song Maréngo was used in my conceptfilm (unfinished) 'Baduy life and music'. I showed this film on my laptop to a few Baduy leaders in December 2013 for feed-back. Apparently the included audio recording of ritual angklung with the song Maréngo was a problem. The secular village head Daénah thought it should only be used for documentation and not included in a film for the general public. I promised to do so. See further Section 3.2 above, Figure 27 and Van Zanten (2015: 120). This feed-back emphasized that this ritual, the engagement and marriage of the rice goddess to the earth, is at the heart of Baduy religion. It is not very surprising that the Baduy leaders did not want it to become easily available to the general public in a film. 


\subsection{Circumcisions and Weddings}

This section will describe circumcision and wedding rituals from literature. The following sections of this chapter describe two Baduy circumcision rituals and part of a wedding that I was able to attend in July 2016, mainly focusing on the performed music and dance. Weddings mainly take place in the about $2-3$ months period after the end of the agricultural year and after the séba ceremony, that is, roughly between June and August (Baduy months Kanem, Kalima and Kapitu). The secular village head Saijah told me that there are about 20 weddings each year (A2016-1: 2-3). When I talk about 'weddings' I mean the 3-day long wedding rituals (kawinan, nikahan) that involve music and dance. However, in the year before the wedding there is the formal proposal (lalamar), and the male candidate working on the fields of his future parents-in-law that are part of the wedding ceremonies that will not be discussed here.

Weddings may also take place in the weeks before the fasting months, around January. This may be a relatively new development. Jacobs and Meijer (1891: 75) report that weddings only take place in the Baduy months Kalima and Kanem and this is more or less confirmed by Geise (1952: 92). Hasman and Reiss (2012: 36, 82-84) report: 'Weddings take place either in the month of Kalima (5th month), a few days before or after the annual pilgrimage to the Sasaka Domas, or in the month of Kapitu (7th month), just before rice-planting. In this book Reiss also gives a description of an Inner Baduy wedding (Hasman and Reiss 2012: 82-84).

However, Kurnia and Sihabudin (2010: 186-187) report that, whereas Inner Baduy weddings may only take place in the Baduy months Kanem, Kalima and Kapitu (roughly June-August), the Outer Baduy weddings may not only take place in these months, but also in all the other months, except for the three kawalu months and the month Sapar (hence with the exception of roughly February-May). They also report that the months from August-January are not often used for marriages; if used, it is mostly for a second marriage of a widower. ${ }^{7}$ Hence it may be that for the Outer Baduy the wedding season became longer during the last few years. I have only heard about an Outer Baduy wedding outside the June-August period in January 2014; it was the wedding of the son of the secular village head Daénah and at that time the keromong was played.

7 As mentioned in Section 1.1, the Baduy are monogamous, but allowed to divorce and marry again. 
Circumcision of boys (sunatan) may only take place in the months after the harvest and séba ceremony (around June-August), and not around January. ${ }^{8}$ According to secular village head Saijah in 2016 there would be 615 circumcisions in Kanékés (A2016-1: 2). Circumcisions only take place once in three or four years and in a limited number of hamlets (see also Kurnia and Sihabudin 2010: 207). There are years in which no circumcision takes place in Kanékés. Over a longer period, on average there will be about 150-200 circumcisions each year. ${ }^{9}$ The circumcisions take place for a group of boys in one hamlet and some neighbouring hamlets, which also happens in other parts of Sunda. During the circumcision of boys there may also be girls in that hamlet and some neighbouring hamlets that will be 'circumcised'. For the girls this means that they will be initiated into the world of the grown-ups by filing of their teeth (geseran, gusaran; see below). This ritual takes place when the children are mostly five to eight years old, and definitely before they are ten years old.

Male circumcision (sunatan) includes the removal of the foreskin from the penis and is a real operation by a male Baduy specialist: béngkong. From my observations it seems that most béngkong are Inner Baduy and this is confirmed by Kurnia and Sihabudin (2010: 206). The night before this operation the teeth of the boys are being filed. For the Baduy girls undergoing the 'circumcision' at the same time as the boys, it is different. For them the only physical change will be the tooth filing during the three-day long rituals. Permata (2001: 54) describes the Baduy female circumcision (peupeuran) as 'not involving cutting anything away from the sexual organ, but cutting hair of the head at the front side' (cukuran) by a woman specialist. ${ }^{10}$ Unfortunately, Permata is not very clear about the peupeuran and the period in the life of a girl when this cutting of hair takes place. I understand that a Baduy girl's physical 'operation' on her sexual organ has already taken place when the girl is about 30 days old and on that occasion the hair is also cut (cukuran). When the girls are 5-10 years old, and attending the sunatan ceremony for boys, they only undergo the physical tooth filing.

Erwinantu (2012: 45-46) reports that the girls are very young when they undergo the hair cutting ritual (cukuran) and Kurnia and Sihabudin (2010: 203) call the hair cutting (cukuran or ngalaan sawan) the last step of the 'ceremonies

$8 \quad$ Jacobs and Meijer (1891: 72) report that circumcision can only take place in the Baduy month Kalima.

9 These figures correspond to roughly 1.3-1.7\% of the Baduy population.

10 Upacara ini [peperan] bukan memotong bagian tertentu alat kelamin, melainkan memotong rambut bagian depan. Pemotongan rambut dilakukan oleh béngkong bikang atau juru aés "dukun sunat perempuan".' 
around the birth' (upacara kelahiran), but they do not say at which age it takes place. According to Erwinantu it includes the cutting of only two hairs at the front side and saying prayers for the well-being of the child by a specialist. ${ }^{11}$ That the Baduy female 'circumcision' of 5-10 year old girls does not have much physical impact was confirmed to me when I attended two circumcisions in July 2016.

There is little information on female circumcision with the Baduy and the existing information is conflicting. Jacobs and Meijer (1891: 73) reported that there is no circumcision of Baduy girls. Kurnia and Sihabudin (2010: 204) report that female circumcision involves 'cutting away/removing a piece of skin ... from the vagina of the girl' (memotong/menghilangkan selaput (sebagian kulit) ... vagina pada perempuan), however they do not supply information on when this takes place in the life cycle of a girl. In the Bandung region the female circumcision was described to me as happening at a very young age and having little physical impact. Rikin (1973: 11-14) briefly describes the female circumcision (ngabersihan budak awéwé or nyunatan budak awéwé) in the wider Sunda region as taking place mostly when the umbilical cord falls down (puputan), and meant to get a drop of blood by taking away a small part of the skin of the clitoris. Williams (2001: 88-89) mentions that female circumcision in the Bandung area takes place for all girls when they are ten days old and 'a small incision is made at the lower base of the clitoris'.

Eringa (1984) and KUBS (1976) list the word peper, and give meper(an) as the refined (lemes) form of ngagusar(an), tooth filing. Eringa (1984: 275) also mentions that gusaran, peperan and tetekan, tooth filing, are also used as a euphemism for female circumcision. It seems that Baduy 'circumcision' of girls (peupeuran), or initiation of $5^{-10}$ year old girls into the world of women as Permata calls it, only consists of tooth filing. The actual incision in the clitoris has already taken place just after birth. For girls the tooth filing may take place at the time when it is done with the boys, just before the sunatan operation of the boys, but also during weddings.

Tooth filing (geseran) is part of the circumcision ritual for Baduy boys and girls that takes place in the evening before the actual circumcision of boys in the morning of the last day. Whereas in the past the tooth filing could be a 'very painful operation' with crying children (Jacobs and Meijer 1891: 72) in current practice the teeth are just slightly touched with a kind of grindstone which is a symbolical way of indicating that a child has entered the world of the adolescents and

11 Hasman and Reiss (2012: 103) describe the cukuran ritual as 'haircutting ceremony for baby's first hair'. This would mean that it precedes the peupeuran ritual taking place when the girls are between five and ten years old. 
grown-ups (Permata 2001: 54). The light physical impact of the tooth filing may be a reason that Baduy 'circumcision' of 5-10 year old girls can also take place during weddings. Whereas 'circumcision' of 5-8 year old girls (sunat awéwé) may take place at the same time as weddings, boys cannot be circumcised during weddings (A1992-1: 48), as it includes a real operation of the penis.

The actual circumcision of boys should take place on Monday morning or Tuesday morning, according to Ayah Anirah (A2016-1: 44). This was in line with the two circumcision rituals that I attended in 2016: in Kaduketug on Monday morning 4 July and in Cicakal Leuwi Buleud on Tuesday morning 5 July (month Kalima and presumably 2 th and 3oth day)..$^{12}$ Sections 4.4 and 4.5 below will describe these circumcision ceremonies in 2016, focussing on the performing arts during the three-day long feasts. More information may be found in Permata (2001: 53-55) and Kurnia and Sihabudin (2010: 190-191, photographs, 204-216).

It seems that the nation-wide (and world-wide) discussion on Female Genital Mutilation/Cutting (FGM/C) since about 2005 has not really affected the Baduy practices on circumcision. Sarah Anaïs Andrieu (personal communication 13 March 2018) told me that in her recent research in the Bandung and Subang areas it also turned out that girls are usually physically circumcised at the end of the birth rituals and before the 35th day after birth. Mostly the practice consists of just pricking the clitoris in order to get a drop of blood. Actual removal of the clitoris also occurs, but seems to be a much more recent and urban practice and, according to government regulations, this had to be done by a medical specialist (official bidan, midwife). According to Andrieu the girls' circumcision mostly includes piercing the two ears (tindik) and cutting some hair (cukur) as well.

The Baduy circumcision rituals take three days. ${ }^{13}$ For this purpose a special temporary awning (papajangan, A2016-1: 9, or saung sunatan; see also Section 6.4) will be built where all the major activities will take place: filing of teeth and actual circumcision of boys and the pantun storytelling performances during the three nights. The baksa dance takes place outside but near this temporary awning. The keromong playing is also done at a different place, on a stage

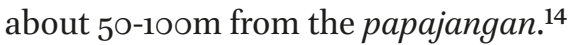

12 Kurnia and Sihabudin (2010: 206) mention that circumcisions are preferably taking place on a Tuesday or Thursday morning, and should not take place on Friday or Sunday morning.

13 The first day is called kumpul leutik ('small meeting'), the second day is called kumpul gedé ('big meeting') and the third day is called bubaran ('break up', 'separate') (A2016-1: 9).

14 On both occasions that I attended, the keromong was playing on a stage located south of the papajangan. 


\subsection{Circumcision in Kadujangkung}

In July 2016 I attended the last two nights of the circumcision activities in Kadujangkung at the end $\left(25^{\text {th }}-26\right.$ th day?) of the month Kalima. I got permission to attend under the condition that I would not take photographs, nor audio or video recordings. Also, I was not allowed to see what was going on in the temporary awning (papajangan). Hence I could only observe from just behind the white cloth of the papajangan what was going on, talk to people sitting outside the awning and take notes. In Kadujangkung there were 24 boys and 3 girls that would be circumcised; two of them came from another hamlet. I did not attend the first day of preparations with a pantun performance during the night (Friday 1 July to Saturday 2 July), because Mumu and I had just arrived in Kaduketug in the afternoon of 1 July and not yet heard about the circumcision. I only attended the second pantun performance on Saturday night 2 July, which lasted from about 21.05 to 23.50 o'clock (that is, two hours and forty-five minutes long) and the third one during the Sunday-Monday night of 3-4 July from 1.42-2.50 o'clock early Monday morning (that is, lasting for just over one hour). Further, I heard and saw the keromong playing during these two days.

On these two nights the pantun performer was Harépin (alias Hanip, Sanip?) from Karahkal, a young storyteller, who learned the storytelling from Ayah Anirah, mainly by listening to his performances (A2016-1: 41). Harépin recited the story without accompaniment on the kacapi. I was told that he had also not used a kacapi during the first evening. When I asked which pantun story was being performed, the people attending replied that they did not know. Most probably it was an episode from the Matang Jaya section of the Langga Sari story (see Section 6.2 below and A2016-1: 43) that is used for weddings and circumcisions. In an interview on 10 July 2016 Ayah Anirah told that the tooth filing (geseran) always goes together with the circumcision and the pantun recitation used (on the third day?) tells about how to do these things: the episode of Béngkong séda sakti ('the sacred person who carries out the circumcision') taken from the Langga Sari story (A2016-1: 44; see also Section 6.2).

The temporary awning (papajangan) of size $4-5 \mathrm{~m}$ by $3-4 \mathrm{~m}^{15}$ was built on the main north-south road of Kadujangkung and open on the east side, facing the houses lying a little higher than the road. During the pantun storytelling I could hear, but not see, what was going on from the veranda of a house just behind the awning on the west side of the road. From there I could also

15 See photograph of such temporary awning (called saung pasajén) in Kurnia and Sihabudin (2010: 205). 
observe the baksa dance, later performed outside the awning. About $50 \mathrm{om}$ to the south of the awning there was a temporary stage of about $5 \mathrm{~m}$ by $4 \mathrm{~m}$ built for the keromong group. The keromong group faced north, that is, towards the circumcision awning. I could go there and watch the group playing, singing and dancing.

The pantun recitation of the second night could clearly be heard from my position just behind the awning. The style of singing was similar to what I had heard before (in 1977, 2003 and 2014). In my notes I wrote that in certain parts the performer Harépin seemed not sure about the text and that his singing was 'melodious' to me. It was difficult to catch longer phrases of words, but I heard him reciting 'Tumpang Parungkujang', 'Nagara Pasir Batang' and 'Pakuan', 'beresihan.' ${ }^{16}$ After the almost three-hour long pantun performance it became quiet around midnight. My assistant Mumu and I did not walk back to nearby Kaduketug (a walk of about fifteen minutes), because of the rain and slippery road, but slept at the house of Lambu, son-in-law of Aki Armad (alias Hamdan, a musician that I had recorded a few times).

The next morning we walked back to Kaduketug but returned to Kadujangkung at 17.30 to see the baksa dance and hear the third pantun recitation and keromong playing at the circumcision ritual. As there had been heavy showers that afternoon, it was very muddy near the awning and when we arrived several men were making a 'dancing floor' of about $2 \mathrm{~m} \mathrm{x} 4.5 \mathrm{~m}$ by laying poles on the ground and covering these with planks. Later a rug of about $2 \mathrm{~m}$ by $2 \mathrm{~m}$ was put over the planks. The men also fixed a pair of scales near this stage and below the awning. These scales were meant to weigh the children to be circumcised that were born in the Baduy month Sapar (see also Kurnia and Sihabudin 2010: 210-211). These children born in the month Sapar are supposed to be aggressive and to become easily angry. Putting these children on the scales with blocks of wood on the other side would help correcting the shortcomings of their character, it was said (A2016-1: 11-12).

When we arrived at 17.30 already many people had gathered near the awning for attending the baksa dance. At a quarter to six it was already pretty dark and I wondered whether I would be able to seen much of the baksa dance later on. Around 17.55 the boys to be circumcised left on the backs of their father, uncle or grandfather and were led to the river by two Inner Baduy men, one of them being the béngkong, who would do the operation. Five minutes later the three girls left for the river carried by their mothers. There they would

16 Beresihan, literally 'cleaning', 'purification', also means circumcision. See Chapter 6 for the names Parungkujang (village or kingdom), Nagara Pasir Batang (kingdom) and Pakuan (capital of Pajajaran kingdom). 
be ritually cleaned after the tooth filing of both boys and girls (geseran) that had taken place earlier that afternoon (Ayah Anirah, A2016-1: 17). A few days later the pantun storyteller Anirah told that at that time near the river a net is thrown over the boys and a short section of the pantun story Langga Sari is recited by the storyteller (A2016-1: 42).

Around a quarter past six the keromong started to play, although I could not hear it very well, because of the distance and the talking people around us. Then the men with the boys, followed by the women carrying the girls, came back from the river and were cheered by the people attending. They went into the awning. Around 19:0o there was the nyawér/sawér: raw rice mixed with pieces of money was thrown to the children to be circumcised, who were beautifully dressed and came out of the awning. A solar lamp was placed above the floor for the baksa dance.

While it was raining the baksa dance was performed by four men carrying boys (their sons, grandsons, or nephews) on their arm from around 19.25 to 19:30. Again the audience threw rice and money to the dancers with the boys. As it was very crowded, I could not observe the dancing very well, but noticed that the movements were fairly slow. Four men in two pairs danced in a row towards each other, passed each other while dancing and then turned around and repeated this pattern. One pair kept kitchen utensils in their hands: one had a spoon and coconut bowl and the other a fan and a rice spoon. The other pair of men both had a kris in their hands (A2016-1: 17, 22). The dance movements were relatively slow and the thighbones were lifted high. The keromong was playing during this first performance of the baksa dance. See photograph of baksa dancers in Kurnia and Sihabudin (2010: 190-191): one dancer holding a large spoon and coconut bowl in his hands.

The keromong was playing most of the time in the evening. The group came from the nearby hamlet Karahkal and included three female vocalists and one male vocalist who also announced the songs. What I saw was almost the same as what could be seen outside Kanékés when a gamelan group plays: the female vocalists/dancers (ronggéng) also dance with men, while another female vocalist sings. Around 23 hours, when the song Kidung Rahayu was played with one of the female vocalists dancing, a man entered the stage throwing around paper money and he started to dance with a ronggéng. Unlike the other parts of Sunda, the keromong did not include drums, as it is not allowed. However, it included a second xylophone (gambang) producing the drum beat: the 'drum xylophone' (gambang kendang; see also Van Zanten 2015: 119). The sound of the keromong was amplified by using electricity from a battery. The quality of the sound was fairly reasonable, which is not often the case when the sound is amplified in Sundanese villages. Apart from the song Kidung Rahayu I heard the songs Buah 
Kawung, Kangkréng and Gadis Subang announced by the male vocalist. There was dancing going along with almost all the songs, also dancing by two men.

The keromong kept playing when the elders had taken their seats in the awning and the pantun storyteller started his performance around 1.42 early Monday morning 4 July. In my notes of that time I remarked that the amplified keromong sound seemed to 'violate' the soft pantun singing. What would the elders think about this? I could hardly hear the pantun storyteller, who was sitting about $3-4 \mathrm{~m}$ away from me. ${ }^{17}$ At 2.50 the pantun recitation was finished and the keromong kept on playing. Mumu and I slept from about 3.00-6.0o at the house of Arpani about 2om away from the awning, where many people had already found a place, including haji Nalim from Margaluyu. ${ }^{18}$

Around six o'clock we went back to the veranda of the house directly behind the awning where the boys were now actually operated. There was already a big crowd present. Relatives and friends, I presume, threw small packets with sweets and chips (ending the nyawér/sawér blessing) to the assembled people after a boy had been circumcised. These packets were collected by the children present. Many men were walking around and carrying a cock. When the men from inside the awning shouted, the head of a cock was cut, almost at the same time of the boy's circumcision. Such animal is called béla by Jacobs and Meijer (1891: 72) and Kurnia and Sihabudin (2010: 191-192, photographs, 215-216). ${ }^{19}$ The boys cried when they were operated, but not all, it seemed. Then fried chicken was carried into the awning and also to the officials and elders staying in the house next to where Mumu and I were seated and near the awning.

Around 6.32 I heard a gong beat. Although we had been informed that there would again be a baksa dance, I did not yet see a dance floor on the muddy

17 This would be repeated the next night at a circumcision ritual in Cicakal Leuwi Buleud: the soft pantun recitation 'disturbed' by the loud keromong playing (see below). My assistant Mumu told me that during the wedding of jaro pamaréntah Daénah's son in January 2014 the keromong was also playing during the pantun performance. See further the end of Section 4.5 below.

18 See also Section 5.4: Nalim is the eldest son of the former secular village head Samin, who migrated with several Baduy families to Cipangembar in 1978. Like his father, Nalim became Muslim and the Indonesian authorities, financially assisted by Arab countries like Saudi Arabia, paid for his pilgrimage ( $h a j$ ) to Mecca (Van Zanten 2004: 140-141; see also Suryani [2020]: chapter 3, section B-1 and chapter 4, section A-3).

19 In July 2016 it was said by Nurman at the house of the secular village head Saijah, that such chicken should be a 'biological' one, that is, been raised in Kanékés without getting vaccinations (obat). Before slaughtering the chicken one should honour the animal and ask its permission to do so (A2016-1: 2). Compare also the formulae in which the sugar palm is asked permission to cut it and take its juice (Van Zanten 1989: 96, referring to Pleyte 1913, Vierde Stuk: 56-57). 
road. At 6.48 someone shouted 'play the gamelan' (takol keromong) and four men started to dance the baksa on the floor that was made yesterday and now covered with mud. One pair of dancers both carried a kris and the other pair kitchen utensils, like the night before, and the style of dancing was similar: slow movements and lifting the thighbones high. However, this time the men did not carry a boy. It seems that the pair of dancers carrying a kris are always two of the (Inner Baduy) béngkong and the other pair consists of elders. One pair $(\mathrm{O}-\mathrm{O})$ danced in a row towards the other pair in a row $(-\bullet)$ and they passed each other in the middle, standing on a line in which the members of the two pairs alternated each other: $\mathrm{O}-\bullet-\mathrm{O}-\bullet$. The two pairs then went on dancing in their own direction, moving away from each other for about $2 \mathrm{~m}$. The two pairs then turned back and again approached each other from the other direction. This was repeated several times. One man did as if he was drinking from the coconut cup. The audience frequently laughed and threw raw rice and money (nyawér) to the dancers. The baksa dancing went on for about five minutes and stopped around 6.54, but the keromong kept playing.

At 7.01 the first circumcised boy was carried home by two men; his penis was uncovered and could be seen by all. Gradually all circumcised children were carried home and given fried chicken and other nice food to eat. The sunatan and peupeuran ritual came to an end and the officials and elders started to leave. I also left with Mumu and arrived at the house of jaro pamaréntah Saijah around 9 o'clock.

\subsection{Circumcision in Cicakal Leuwi Buleud}

On arrival back from the circumcision in Kadujangkung, jaro Saijah told us that he would like to go to a sunatan ritual in Cicakal Muara ${ }^{20}$ and asked whether we would like to go with him. We happily agreed and left around 10.45, after having a wash and some food. We walked the distance in about an hour and arrived when the keromong was playing. It was the second day of the sunatan and peupeuran (peperan) ritual for 32 boys and 5 girls. We could stay with the head of the hamlet (RT) Ayah Caikin. I got permission to take photographs and audio record the keromong. The keromong played on a stage lying about 4om south from Ayah Caikin's house. In between, on the left side of the paved footpath, was the temporary awning (papajangan) for the boys and girls who

20 It appeared to be the hamlet Cicakal Leuwi Buleud that borders Cicakal Muara that lies in southwest direction. 


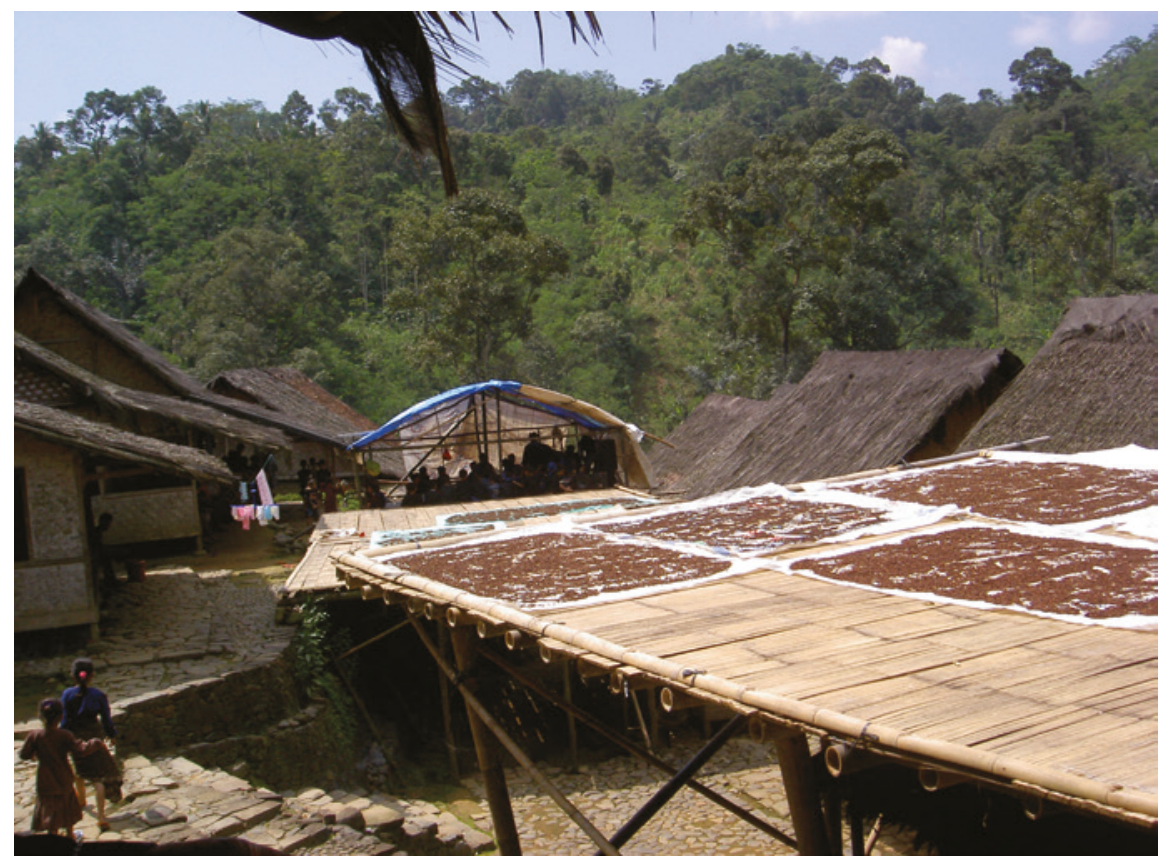

FIGURE 33 The position of the keromong stage used during the circumcision ritual, when looking in southern direction from the house of the head (RT) of Cicakal Leuwi Buleud, midday 4 July 2016

were undergoing the circumcision and tooth filing, about 1om from the RT's house. See Figure 33. The entrance to the awning has to be on the east side and was therefore visible from the footpath. It lies left from where the two girls are walking left-below in the picture. In front are cloves spread out on mats and drying in the sun. According to jaro Saijah and Ayah Caikin the awning was covered with white cloth (boéh larang), which I could later see for myself.

The keromong played most of the afternoon and I could make some audio recordings from the house of Ayah Caikin. Around 16 o'clock there were both male and female vocalists. I heard the song Kidung Opat-lima announced. Many men were carrying food around. I noticed three Inner Baduy passing by, who walked to the awning. One of them carried two round 'shields', as used for winnowing pounded rice. The keromong started to play without vocalists around 17 o'clock. This possibly indicated that the tooth filing took place in the awning, as it happened similarly the next morning during the actual circumcision: instrumental music with short patterns that were repeated over and over again. The amplification system was not as good as in Kadujangkung, and the sound was fairly distorted. Ayah Caikin (RT of Cicakal Leuwi Buleud) told 
that in their hamlet the amplification of the sound with a battery had started about two years ago (2014). After the Indonesian government decided to cut the subsidy on paraffin and other oil products about four years ago, many Baduy bought batteries that could be charged with solar cells. This also started the introduction of the amplification of the keromong sound, they told. Kurnia and Sihabudin (2010: opposite p.191) supply a photograph in which a female vocalist is using a microphone when singing with a keromong at a circumcision party; unfortunately they do not supply any information about date and place.

The boys and girls got nicely dressed and 17.45 the group of boys left, carried by their fathers, for the ritual washing in the river. The girls with their mothers followed at 17.49. At 17.55 the boys already came back. Then there was the baksa dance for about five minutes; I could not see it very well, because it was crowed in front of the awning. People threw coins and raw rice (nyawér) to the boys carried by their fathers (or grandfathers, uncles).

Around 23.30 the pantun storyteller, Ayah Yaldi, started his recitation. However, a few moments later the keromong also started to play with amplification and it was almost impossible to hear the soft pantun singing from the road, about $4-5 \mathrm{~m}$ from the singer, where we stood. Around midnight the keromong stopped playing and there were at least four officials who delivered a speech, using the amplification system. The first speech was by a representative from Cicakal Girang, the Muslim enclave in Kanékés. The second speech was by the RW (head of group of hamlets, Behong) and the third one by the RT of Cicakal Leuwi Buleud, Ayah Caikin. The last one wished that the ritual of the sunatan that was now going on would proceed in a proper way. At last the former secular village head Daénah gave a speech in which he underlined the importance of social security. The speeches ended around a quarter past midnight and five minutes later the keromong started playing again with a female vocalist. At 00.28 the song Kidung Rahayu was announced and played. In the meantime there was the pantun recitation going on that we could hardly hear, so that we decided to go to the house of the RT and sleep there from about 00.30-05.30.

We woke up because there were many people assembling near the awning. Around 05.50 the parents carrying their children to be circumcised, departed to the river, led by the two Inner Baduy béngkong who would later do the operation. No one followed the group for this purification ceremony at the river. Ten minutes later, at 6 o'clock, the first fathers with their sons already came back. Like in Kadujangkung the day before, there were many men walking around with a cock. The keromong was playing relatively monotonous music. I heard men shouting and small packets with sweets and chips and coins of money were being thrown to the audience (nyawér). At 6.17 I heard the first boy crying. Repeatedly the coins and sweets/chips were thrown into the audience by 
the family members (mostly women, it seemed) of a boy that had just been circumcised.

The baksa dance started a few minutes before seven and lasted 4-5 minutes. The four performers were the two operating men (béngkong), ${ }^{21}$ who both carried a kris, Ayah Anirah, who carried a coconut cup with a large spoon, and another man who carried a fan with a rice spoon. The way of dancing was the same of what has been reported from the day before in Kadujangkung: one pair of dancers with a kris dancing towards the other pair with kitchen utensils. They passed each other, danced a little on, turned around and started again dancing towards each other. This was repeated several times and the public was laughing. The thighbones were lifted high and the movements were slow, when compared to other Sundanese and Baduy dancing.

The keromong had been played almost continuously since 6 o'clock. Shortly after 7.00 the circumcised children were carried home. Some of the children were entirely naked. Also the public was going home after the baksa dance. Around 7.45 the keromong stopped playing. There were many men running around with food (cooked rice with banana leaf on top, it seemed) for the officials and guests. In my notes I wrote that it looked like a well-organized ant heap: apparently everyone knew exactly where he should be going with the food he carried.

At 8.45 the keromong started playing again, including vocalists. I noticed a teenaged boy who sang and another boy who danced a kind of pencak (but called topéng $)^{22}$ on the music; see Figure 16. I took photographs of the keromong instruments: two caning metallophones with 6 keys, a panerus (one octave lower than caning), keromong instrument with 10 kettles, two large gongs, viol, one gambang xylophone for melodies and one gambang kendang (drum xylophone), cemprés cymbals. See Figures 38, 39 and 40. Mumu and I departed from Cicakal Leuwi Buleud for Kaduketug around 10 in the morning of 5 July 2016.

Especially after this circumcision ritual in Cicakal Leuwi Buleud I was surprised that the soft pantun recitation was going on at the same time as the loud, amplified keromong playing. In the past, when the keromong was not

21 Ayah Anirah told us that they were his elder and younger 'brothers' from Cikartawana in the Inner Baduy area.

22 I do not know why the Baduy use this word 'topéng' that is used for mask dance, or mask dancer in most other parts of Sunda. In Indonesian topéng means 'mask', whereas the Sundanese use kedok for a wooden mask. As far as I know, Baduy do not use masks. Budi (2015: 128, 326) describes topéng in the Kasepuhan Ciptagelar near Kanékés, as a kind of 'play or traditional drama' (sandiwara atau drama tradisional) or 'folk theatre' (teater rakyat). 
amplified in such situation, it may have been that the audience was still able to hear the pantun performer, because the performing sites were at different places. However, with the amplification of the keromong, there is certainly no proper balance. What is the reason that the pantun recitation (without amplification) is still performed together with an amplified keromong?

In other parts of Sunda it also happens that there are many music and dance groups playing together in one procession. For instance, I reported this for the bénjang processions that I saw in Ujungberung in the eastern part of Bandung, held on the day before boys would be circumcised (Van Zanten 1989:14-15). The many performing groups and people watching make such occasion ramé: exciting, lively, animated, and bustling. In 1992 I attended the Baduy ritual in which the rice goddess Nyi Pohaci was married off to the earth (Section 4.2 above). In Van Zanten (1997: 47-48) I noted about this occasion:

Three angklung groups from different villages [hamlets] were involved. Most of the night the three groups played together. As the sets came from three different villages [hamlets], their tuning did not match very well. Generally speaking, musicians and audience clearly hear these imperfections and will not accept them. However, at this occasion the communal feeling was apparently thought to be more important than the exact matching of the tunings of the three angklung sets.

The important social quality of a ramé occasion is also stressed by Budi (2015: 327).

\subsection{Weddings and Other Rituals; Some General Observations}

The actual wedding ritual also lasts for three days, like the circumcision ritual. The Inner Baduy are married by the head of their hamlet (jaro tangtu), with the consent of the puun. For Outer Baduy the ritual includes a wedding by a Muslim official (panghulu) in the Muslim enclave Cicakal Girang, after the puun has agreed to the marriage (see also Section 2.3). Danasasmita and Djatisunda (1986: 71) remark that the puun only gives permission to marry, if the Outer Baduy couple has promised not to become Muslim. This is relevant, because during the ceremony the man will be asked to pronounce the confession of faith (syahadat panamping): 'I confess there is no other god than Allah, I believe in Muhammad his prophet' (Garna 1988: 104). This ceremony in Cicakal Girang also includes the official registration for the Indonesian authorities, like in other parts of Indonesia. It is followed by a Baduy wedding ceremony in the 
hamlet of the woman, similar to what happens in the Inner Baduy area. Hasman and Reiss (2012: 9) talk about an 'official Muslim wedding followed by a traditional Kanékés wedding' for Outer Baduy couples.

A marriage is always endogamous, that is, between a man and woman who are both of Baduy descent. Only by exception an Inner Baduy may marry an Outer Baduy. Also, only in exceptional cases a non-Baduy is allowed to join the community and marry an Outer Baduy. Baduy are monogamous, but they may divorce and marry again. This is not simple for Inner Baduy: if two Inner Baduy want to divorce, this is only allowed if they become Outer Baduy. It seems that the Outer Baduy divorce almost as often as the surrounding Sundanese. That is, possibly $40 \%$ of the marriages (or more) end in a divorce, and both man and woman may marry again after a divorce. ${ }^{23}$ See for more information on weddings, for instance, Geise (1952: 152-161; for Baduy and for Muslims around Kanékés), Danasasmita and Djatisunda (1986: 68-71), Garna (1988: 98-123), Ekadjati (1995: 86-90), Permana (2001: 56-62; only for Inner Baduy), Hasman and Reiss (2012: 36-37, 82-85).

The music played at Outer Baduy weddings may be keromong and pantun. It seems to depend largely on the financial means of the involved families, which music performers will be invited. Whereas a circumcision involves several families that may share the costs, a marriage mostly involves less families, and therefore the financial burden cannot be shared with many. The marriage of Daénah's son Pulung took place at the house of the secular village head from 6-8 (or 7-9?) January 2014. Mumu attended this occasion and with his hand phone he made a film of the dancing with the keromong. He then also heard a pantun performance (only singing) at the same time that the keromong was playing: for jaro Daénah this was no problem, as he is relatively rich.

In 2016 I heard of three Outer Baduy weddings: in Cicakal Leuwi Buleud on 12-14 July, in Ciranji on 18 July and in Cipondok at the beginning of August (?) On 13 July 2016 we passed Cicakal Leuwi Buleud and saw wedding festivities going on. It was the wedding of a child of the hamlet's head (RT Caikin), where we had earlier spent the night during the circumcision festivities (see Section 4.5 above). We arrived around 13.00 on the last full day and there was keromong playing going on. It was the same local keromong used about a week earlier for the circumcision festivities (see Figure 16 and Figures 38-40 below). The people present told us that there would be no pantun storytelling that night.

Reiss described a wedding ceremony in the tangtu hamlet Cibéo that she was allowed to attend (Hasman and Reiss 2012: 82-85). She highlighted the important

23 For the whole of Indonesia $15 \%$ of the 2 million marriages in the period $2010-2014$ ended in a divorce before 2015. See https://lifestyle.kompas.com/read/2015/o6/30/151500123/ Kasus.Perceraian.Meningkat.7o.Persen.Diajukan.Istri. [last access 27 March 2020.] 
role of textile, in particular woven clothes, in the exchange between the families of bride and groom, ${ }^{24}$ but also supplied some interesting information on music played during the ceremony. She described that 'at twilight before the wedding day'25 she went along with friends to a shelter in the rice fields (saung huma) that was about one kilometre away from Cibéo. The bride was waiting there with close friends. As the party accompanied the bride back to the hamlet '[t]wo boys played haunting bamboo-flute music'. That evening a pantun story was recited at the house of the bride's father by 'an elderly man from Cikartawana' who accompanied himself on a kacapi. ${ }^{26}$ While listening to the epic story, the women wrapped the cooked chicken and rice, prepared during the afternoon, in parcels 'for the guests to take home after the wedding ceremony'. This storytelling continued into the early hours of the morning (Reiss 2012: 82, 84).

'Music' is not used in Baduy rituals like birth, death, the fasting ritual kawalu and the harvesting ngalaksa ritual. Also the yearly séba journey to the 'rulers of the north' does not involve Baduy music. In the last few years, when the Baduy arrived in Sérang and had presented their gifts to the authorities, they could attend performances like wayang golék puppet theatre and jaipongan dancing by other Sundanese groups.

Danasamita and Djatisunda (1986: 72) note that, when a Baduy person dies the family and friends should not show their grief in public: their face should have a 'cold' expression. When burying a dead person, there is one of the family members who 'weeps for the corpse' (ceurik panglayuan). This is no real weeping, but saying 'a prayer so that the soul of the dead will arrive in the holy place where the gods live and will not get lost in the underworld: ${ }^{27}$ From this description, it seems that this kind of 'professional weeping' cannot be classified as similar to a lament in the Western sense. However, this needs further investigation. The former Baduy Narja and his brother-in-law Usman from Cipangembar, outside Kanékés, confirmed that there is a song Pangiring Layuan ('accompaniment for the corpse') that may be sung, but mostly after the actual burial on the second or third day. When their own father/father-in law, jaro Samin, died in December 1991 there was pantun storytelling on the seventh day (A1992-1: 30).

A dead person is buried in such way that the feet lie east and the head lies west and faces the south, the direction of the sanctuary Sasaka Pada Ageung

24 Like in many other societies in Indonesia and elsewhere.

25 That is, in the late afternoon, as the start of a day in Kanékés is at sunset.

26 Reiss wrongly described kacapi zithers as 'lute-like instruments', as mentioned earlier.

27 '... pengucapan doa agar sukma si mati dapat tiba di "Mandala Hiyang" dan tidak tersesat ke "Buana Larang".' 
(Danasasmita and Djatisunda 1986: 73). Compare also Sections 2.2 and 6.4. The Baduy do not look after the graves, and there is no graveyard in Kanékés. A grave is only marked with a hanjuang bush. In this respect the Baduy are different from other parts of Sunda and Indonesia, where graves are regularly visited and cleaned by family members and former colleagues (nadran); see, for instance, Van Zanten (1989:54-56). As mentioned in Section 4.1 above, the Baduy believe that the dead stay in the underworld (buana rarang/larang) for seven days, before their spirits go to the upper world (buana luhur, buana nyungcung) where they are united with the gods. See further, for instance, Danasasmita and Djatisunda (1986: 72-74) and Ekadjati (1995: 72-74, 90-92). In March 2003 the secular village head Daénah and the village secretary Sapin also assured me that the bones of the corpse would be gone within seven days after burial; what would be left is the white cloth in which the corpse was wrapped (boéh larang) and the remains of the bier (A2003-1: 17, 22).

Pleyte (1909: 516-517) presents a Baduy formula that will be whispered in the ear of a dying person:

Ong! Ilaing ka ditu

Ulah teu puguh ngajugjugan

Ka ditu ka kawung ngaluuk Ka kalapa anu ngajajar Ka jambé anu ngabérés Ka si gelemeng hideung
Hail to you going there!

Do not refrain from going straight to that place

To that place with the single sugar palm To the coconut trees that stand in a row To the pinang trees that are neatly arranged To the black haziness

In July 2016 I had long interviews with the pantun performer Ayah Anirah, who had lost one of his grandchildren in the beginning of July. He was very sad about this loss, also because his daughter now wanted a divorce. I quoted the above formulaic Sundanese text from Pleyte and asked Ayah Anirah whether this was indeed used for dying people. He replied that the Muslim people have a custom like this, but that the Baduy did not have such formula and he did not know the text that I had cited. The family and friends may weep and there is no whispering in the ear of the dying person. He also told that the pantun story Raja Lumantang that he knew about, but that he could not perform himself, tells about life after death, what human beings can expect after they die (A2016-1: 42, 62). See further Section 6.2.

So far for music as used in major rituals. In the following chapters the different kinds of music and dance will be described in slightly more technical terms, looking at, for instance, how the instruments are built and some technicalities of the music. 